\title{
THE RECEPTION OF DANIEL CHAPTER 2 IN THE COMMENTARY ASCRIBED TO EPHREM THE SYRIAN CHURCH FATHER
}

\author{
Phil J. Botha \\ (University of Pretoria)
}

\begin{abstract}
Ephrem the Syrian (ca. 306-373 CE) was perhaps the most influential Father of Syriac-speaking Christianity. Chapter 2 of the Syriac commentary on Daniel ascribed to him is investigated in this paper: The biblical (Peshi†ta) text the author probably had at his disposal when he wrote the commentary, similarities and differences between the commentary and Ephrem's interpretation of Daniel 2 as it is found in hymns known to have been written by him, and the way in which the text of Daniel 2 was interpreted for Syriac-speaking Christianity in this commentary. A comparison is also made between the exegesis found in the commentary and that of Ephrem's older contemporary, Aphrahat the Persian Sage. The commentary is found to contain ideas very similar to that of Ephrem, so that it is possible that he or someone from his school of thought could have written it.
\end{abstract}

\section{Introduction}

In the second chapter of the biblical book of Daniel, a narrator tells of the dream king Nebuchadnezzar of the Babylonians had during the second year of his reign. ${ }^{1}$ The king wants his magicians and sorcerers to tell him not only the meaning of the dream, but also the dream itself. When they say that that is not possible, he threatens to have all of them killed. Daniel hears of this threat, which is directed at him also. ${ }^{2} \mathrm{He}$ goes to the king and respectfully asks for an extension so that he can seek an answer to the king's problem. He prays with his friends and God reveals the dream and its interpretation to him.

Daniel then tells the dream to the king: There was a huge statue with a head of gold, a breast and arms of silver, an abdomen and thighs of bronze, legs of iron, and feet made of a mixture of iron and clay. A rock was cut loose without hands and it smashed the feet of the image and crushed it all to dust. The rock itself became a huge mountain, which eventually filled the whole earth. Daniel interprets the dream as referring to Nebuchadnezzar and the kingdoms that will succeed his own. After the Babylonians (symbolised by the gold), there will be other kingdoms. It is commonly assumed that the metals refer to the Medes (symbolised by silver), the 
Persians (symbolised by bronze), the Greeks (represented by iron), and the divided kingdom of the Ptolemies and Seleucids (represented as a mixture of iron and clay). ${ }^{3}$

We know today that the final editing of the book of Daniel was made between 168 and $165 \mathrm{BCE}$, since the editor knew about the desecration of the Jerusalem temple by Antiochus IV Epiphanes (168 BCE), ${ }^{4}$ but makes no mention of the rededication of the temple (165 BCE). In Jewish interpretation, the rock that became a mountain would have been recognised as the kingdom of the Maccabees. This kingdom would extend in their expectation to that of the Messiah whose reign would eventually envelop the whole world. ${ }^{5}$ Here one has to keep the Ancient Near Eastern worldview in mind: a flat, circular earth with the mountain of the gods in the north (cf. Isaiah 14:13). In Israel this mountain, the navel of the earth, was seen as Mount Zion, the mountain of God. ${ }^{6}$ The commentary does indeed explain the rock as the kingdom of the Maccabees, but notes that this is a symbol of a greater truth that would come later, namely Christ.

\section{Translation of the Commentary on Daniel Chapter 2}

Despite the heading of the commentary, which describes it as "the Commentary on the prophet Daniel made by our holy Father Mar Ephrem", Ephrem's authorship of this work is not proven or universally accepted. ${ }^{7}$ Baumstark $^{8}$ cautions against accepting second-hand or third-hand witnesses about prose commentaries linked to Ephrem's name. The commentary should thus also be compared to notes found in Ephrem's genuine hymns. For the time being, the commentary will simply be referred to as "the Commentary". A more specific verdict on the possibility of Ephrem's having written the commentary will be made later, after comparison with Ephrem's known work.

The following is a translation of the commentary on Daniel 2. It will be noted that the author quotes sections of the Peshitta text, which is then commented upon. The author does not, however, always introduce his comments with the abbreviation $m$ (for $\Omega m$, "that is"):

And the king said to call the magicians and the charmers: "If you do not make the dream known to me, your judgement is one: through a lying and empty word you agreed to speak before me."

Comment: In the second year of the reign of Nebuchadnezzar, a dream was shown to him but it was concealed from him so that 
while the magicians and astrologers would be ashamed - those who were thinking that through their magic practices and plans they had raised the Babylonian king to honour - Daniel would enter triumphantly through that God whom they considered to be weaker than the gods of Babylon. And the command went out and the wise were to be killed. He thus decreed death on the Chaldeans so that they would be ashamed. If those of the city who were within it were not able to save themselves, how could they declare to have brought out the inhabitants of Jerusalem who were in captivity? And Arioch went out to kill the wise of Babylon. Through his knowledge Daniel thus turned them away from death, those whose ignorance delivered them to the sword. The wisdom was thus concealed from the wise of Babylon, but it was revealed through prayer to Daniel. Let the name of the Lord be praised from eternity and until eternity. Comment: Over everything that he did for our fathers in Egypt and to us who are in Babylonia. The wisdom and the strength are his: because he extended his wisdom and his long-suffering to the Babylonians and their allies as to the Egyptians. But he will also strike them in his strength as he struck the Egyptians. He changes times and seasons. Comment: Those of the four kingdoms that were described in the four parts of the statue. He removes kings and appoints kings. Over them he speaks furthermore on their following the one after the other and their kingdoms the one after the other. $\mathrm{He}$ gives wisdom to the wise. Comment: Since he revealed the dream to the wise that are respectful of God. And understanding to the comprehending. Comment: And the interpretation of the dream to those who know the meaning of the hiddenness of the prophets. Uncovering the hidden things. Comment: The dream and its interpretation and the thoughts of the king that came to him in the evening. And he knows that which is in the dark. Comment: Because he knows everything that is perpetrated in error, it is compared to darkness. And the light is with him. Comment: Everything that is done through the knowledge of the righteous is compared to light. You, o God of our fathers, I praise. Comment: Namely of Abraham and Isaac and Jacob. Because you have given me the wisdom and the strength. Comment: The revelation of the dream and its interpretation. You have made known to me that which we sought from you. That he would not treat wrongly the request of his colleagues, he said: "You have made known to me that which 
we have sought from you". And the word of the king you have made known to me. The thought of the heart of the king you have made known to me. But there is a God of heaven who will reveal to the king what will be in the last (days). Comment: What happens, he shows to you, not only the dream and its explanation which was lost to you and your wise ones and your idols, but also those intentions that were the cause for the appearance of the dream. You, O king, your thoughts on your couch went up on what would happen in the end. The thinking of this Babylonian thus was that because he subdued all the nations and he shamed all kings, there would be no kingdom which could cause his kingdom to pass over. And he said: Listen who it is who will cause it to pass over. A great image, and its head was of fine gold. Comment: It is the kingdom of the Babylonians, that is, of Babylon, the cup of gold in the hand of the Lord. His chest and his arms were of silver. Comment: The kingdom of the Medes. His abdomen and his thighs were of bronze. Comment: The kingdom of the Persians. His legs were of iron. Comment: The kingdom of Alexander. His feet were partly of iron and partly of clay. Comment: These are the ten kings who stood up after Alexander. You are the head of gold. He began the interpretation of the dream here when he said to the Babylonian: You are the head of gold. And since he thought that no rule of mighty (kings) could cause their kingdom to pass, he said "A lowly/humble kingdom." Comment: The kingdom of the Medes will arise and will cause your kingdom to pass. And the kingdom, which is the third, will have dominion over the whole earth. This is the kingdom of Cyrus the king of the Persians who would rule over the whole earth. And the fourth kingdom, which is strong like iron, will, like iron, beat and break everything into pieces. Comment: Alexander is he who subjugated all the nations, and he trampled and pounded each power of chiefs and kings in a similar way that iron prevails over all bodies. And the toes of the feet partly from iron and partly from clay, they are the ten kings who stood up from the kingdom of the Greeks, some of which were hard and powerful like iron and some of which were humble and weak. And further, that while they were intermarried with each other, there were no unity and love between them. Therefore the prophet said over them: And they will mingle themselves / ally themselves namely through human seed, but they will not cling together the same as clay and iron does not adhere to one another. 
And the God of heaven will establish a kingdom that will not pass forever. Comment: This kingdom is to a people not near, for although it was delineated/imprinted symbolically in the house of the Maccabees who subdued the kingdom of the Greeks; in truth ${ }^{9}$ it is fulfilled in the Lord. The rock that was cut out without hands (which was not by hands). For that is the Lord who was born/begotten in feebleness like a rock from the mountain. Comment: From the lineage/descent of the house of Abraham. The Holy Virgin is thus also called "the mountain", for from her he was cut out without hands. Comment: Because there was no sexual union from her, yet the whole earth was filled from her. Comment: He said this over the Gospel that spread everywhere. And Nebuchadnezzar stood up from his throne and worshipped Daniel and made him a chief. And he said: "who has seen anyone like this? For the spirit of the holy gods is in him." The king thus revered the captive and exiled youth and with sweet spices he worshipped him who was dwelling in Daniel, the Holy Spirit who was in him.

\section{The biblical text used in the Commentary}

Similarly to the Syriac text that was available to Aphrahat, ${ }^{10}$ the author of the commentary uses a Peshitta version of Daniel that falls within the Peshitta textual tradition. ${ }^{11}$ He follows this text so closely, that it would be difficult to accept that he quoted from memory. In comparison with the Masoretic Text and the Peshitta, the commentary's quotations agree with the Peshitta in the case of two of the three "pluses" identified by Taylor. ${ }^{12}$ These "pluses" refer to additions in the Peshitta version - words that are not really present in the Aramaic of MT. They are the following:

(1) The addition of the first person singular pronoun after the first of two participles in Dan 2:23 ("I am praising and glorifying you"). MT has a subject pronoun only after the second participle. It should be noted, however, that the commentary omits the second participle and the second occurrence of the pronoun altogether, so that this could be interpreted as a case of agreement between the commentary and MT (if he only left out the second participle and used the second pronoun to identify the subject of the first participle). It could, however, just as well be a case of the author following Syr and simply dropping the synonymous parallel and its pronoun: 


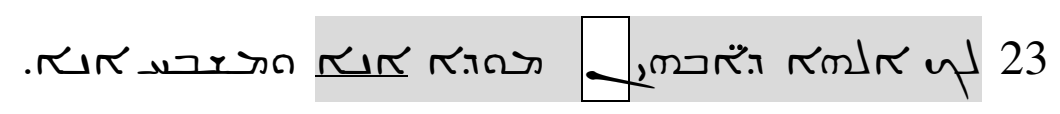

The shaded text is that part of the Peshitta which the author of the commentary quotes. The underlined word is the addition that the Peshitta makes to MT. A noteworthy difference between the commentary and Syr, however, is the use of the first person plural suffix (in the white box) in the word "the God of our fathers". MT and Syr have "the God of my fathers".

(2) In 2:35, the Syriac translator has understood the syntax of MT differently. Instead of MT's "it filled all the earth" (referring to the rock that struck the image), Syr has "and all the earth was filled by it", since the verb ד can either mean "to fill" or "to be full". Syr has added "by it" after the verb, while it is fairly obvious that the Aramaic in MT intends the rock to be still the subject of the 3 feminine singular form, not the earth:

$$
\text { . }
$$

The Commentary follows Syr in this modification. ${ }^{13}$

(3) In 2:42 there is a case in which it would seem that the Commentary agrees with MT against Syr. MT begins the verse with the casus pendens "and the toes of the feet". To this, Syr adds the relative sentence "which you saw", consisting of one word only in Syriac. This is not in the Commentary's quotation. It is probable, however, that the author simply left out the (unnecessary) word and particle, bringing it (unwittingly) in line with MT:

$$
\text { ח }
$$

The shaded areas represent MT, Syr, and the Commentary; the unshaded area is that of Syr alone.

Thus far, it would seem that the matter is undecided, although it would be very difficult to explain how example (2) above came into being if it was not a case of the author of the Commentary using the Peshitta text.

Taylor $^{14}$ also identifies "minuses", words present in the MT but lacking from the Peshitta. In the sections quoted by the author of the Commentary, four such "minuses" occur and the Commentary's quotations display all four of them. They are the following:

(1) In 2:32, MT begins with a casus pendens הוא צלמא ("as for that image"). Syr, and the Commentary, lack this phrase. It is also absent from LXX: 


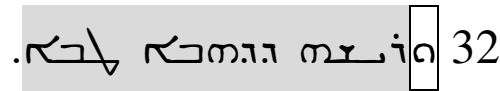

The Commentary has, however, added a copulative waw to the beginning of the verse which is not found in Syr but which is represented in LXX. It must be added, though, that LXX inserts the verb eipl to transform the

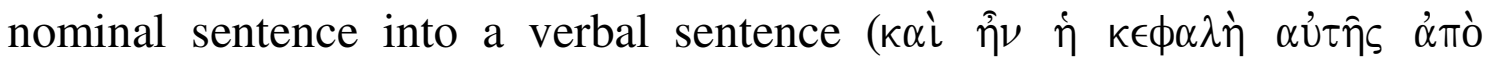

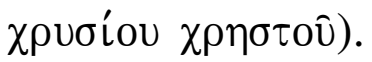

(2) In 2:34, MT, the Commentary, and Syr all differ to some extent:

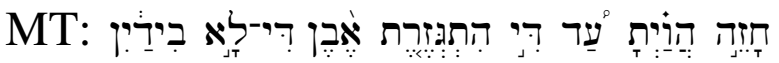

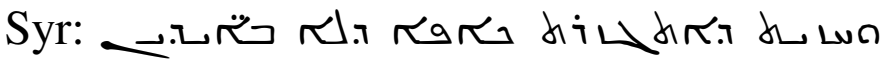

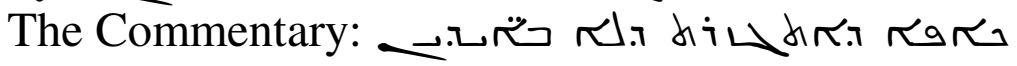

MT's "You were looking until a rock was cut out which was not by hands" is changed in Syr to "And you saw that a rock was cut out which was not by hands". The Commentary simply refers to "the rock which was cut out without hands", a phrase which could be taken to correspond to both MT and Syr, with only a change in word order. Note, however, that the function of the particle $\mathrm{x}$ has changed from a conjunction introducing a subordinate clause ("you saw that...") in Syr to a relative pronoun ("the rock which...") in the Commentary's quotation. But this is simply the result of a change in word order and the Commentary correlates with Syr in leaving out the perfect continuous "you were looking".

(3) In 2:40, Taylor ${ }^{15}$ has noted two "minuses" in the text of Syr in comparison to MT. It is probably worth quoting MT and Syr, with variations by the Commentary, in full. The omissions from MT in Syr are marked by words in an outside border in MT, the Commentary's quotation is shaded in grey and its addition to Syr is enclosed in a box:

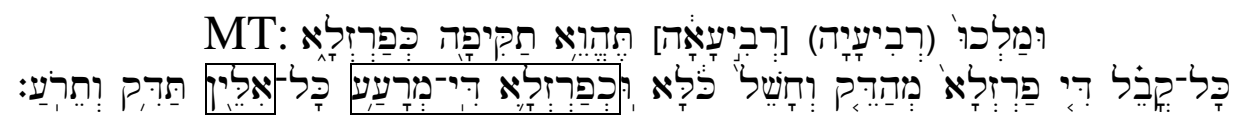

Syr and the Commentary:

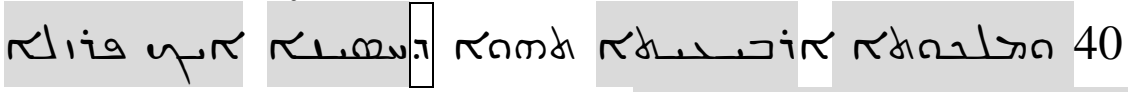

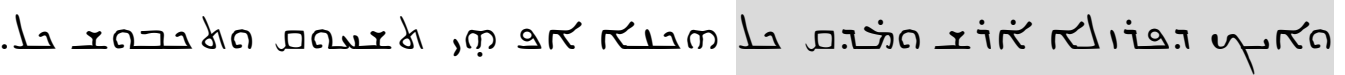

In translation, MT reads: "And the fourth kingdom shall be strong as iron, for as much as iron breaks in pieces and subdues all things; and as iron that crushes all these, shall it break in pieces and crush." Syr translates: "And the fourth kingdom shall be strong as iron, and as iron beats and pounds 
everything, so it also will shatter and subdue all." From this the author of the Commentary has evidently made a selection, inserting the relative particle $\rightarrow$ to facilitate a new, shorter reconstruction. Taylor ${ }^{16}$ notes that the text of MT is difficult because of the twofold occurrence of the phrase "like

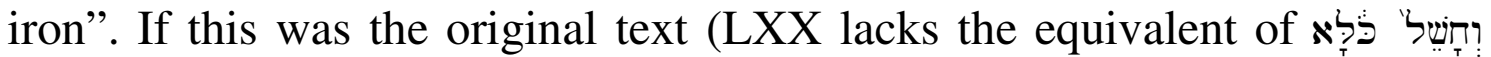

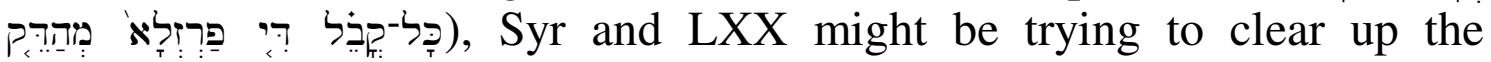
difficulty by eliminating one of the phrases. It is also possible, however, that MT is a conflated text representing two different textual streams. ${ }^{17}$

At the end of this comparison, it can probably be safely said that the similarities between Syr and the Commentary's text are too extensive for it to be mere coincidence. Ephrem, or whoever wrote the commentary, had a copy of the Peshitta, or one very close to the critical edition of the Peshitta which we have today, in front of him when he wrote his commentary.

Apart from the minuses and pluses found in the Peshitta, which are very useful to consult when dependence on either MT or Syr has to be decided, there are other (small) differences between Syr and the Commentary's quotations. Some of these have been encountered in the discussion above, but for the sake of completeness, all are listed below. In none of these cases can one prove that it is because of the author's following another Vorlage that his text differs from Syr. Concerning the segments which the author selected for the commentary, it seems that he quotes 169 words of the 783 words in the Peshitta text of this chapter (21.58\%). He makes the following changes to the text that he quotes:

- Insertion of the preposition $د$ (in verse 9),

- Insertion of an auxiliary verb ( $\cap \circ m)$ (in verse 13$)$,

- Use of a different stem formation with the same root (a/vrs instead

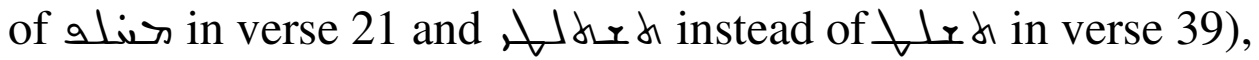

- Substitution of two words with an equivalent consisting of one word

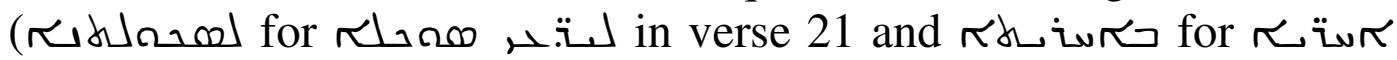
К

- Changing of a first person singular suffix ("my") into plural ("our") (in verse 23 ),

- Using a different genitive construction (twice in verse 23),

- Deletion of a preposition which is substituted by a relative particle ("but there is the God of heaven" instead of "but there is a God in heaven" in verse 28),

- Changing the gender of a verb (ملم, of instead of in verse 29),

- Insertion of a waw copulative (once in verse 32),

- Interchange of words (once in verse 34), 
- Insertion of a relative particle (once in verse 39 and once in verse 40),

- Substitution of a verb with a synonymous equivalent ( حבخ $\sigma^{\text {in }}$ place of Ludid in verse 44).

\section{The character of the commentary on Daniel 2}

\section{(1) Reality and symbolic meaning}

Daniel 2 displays the following structure. The verse numbers in bold underline give an indication of which verses the Commentary quotes from:

\begin{tabular}{|c|c|}
\hline Verse numbers & Contents \\
\hline 1: & The king had a dream. \\
\hline 2, 3, 4: & The interpreters are called to explain the dream. \\
\hline$\overline{5}, 6,7,8, \underline{\mathbf{9}}$ & $\begin{array}{l}\text { The king wants to hear the dream as well as its } \\
\text { interpretation (to prevent the interpreters from lying to } \\
\text { him). }\end{array}$ \\
\hline 10,11: & The interpreters protest that only the gods can do that. \\
\hline 12: & $\begin{array}{l}\text { The king gives orders for the elimination of the } \\
\text { interpreters. }\end{array}$ \\
\hline$\underline{\mathbf{1 3}}, \underline{\mathbf{1 4}}, 15,16:$ & $\begin{array}{l}\text { Daniel hears about the command and asks the king for } \\
\text { deferment of the sentence. }\end{array}$ \\
\hline 17, 18: & Daniel and his friends ask God for mercy in this matter. \\
\hline 19: & The dream and its meaning is revealed to Daniel. \\
\hline$\underline{20}, \underline{21}, \underline{22}, \underline{23}:$ & Daniel praises God for revealing the secret. \\
\hline 24, 25: & Daniel is brought before the king. \\
\hline 26, 27, $\underline{\mathbf{2 8}}, \underline{\mathbf{2 9}}, 30:$ & $\begin{array}{l}\text { Daniel points out to the king that the dream is a } \\
\text { message from God to him. }\end{array}$ \\
\hline$\frac{\mathbf{3 1}}{36}, \underline{\mathbf{3 2}}, \underline{\mathbf{3 3}}, 34, \underline{\mathbf{3 5}}$ & Daniel relates the king's dream to him. \\
\hline 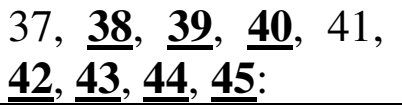 & Daniel interprets the king's dream to him. \\
\hline 46, 47: & $\begin{array}{l}\text { The king worships Daniel and acknowledges his God as } \\
\text { the only true God. }\end{array}$ \\
\hline 48, 49: & $\begin{array}{l}\text { Daniel and his friends are honoured and promoted by } \\
\text { the king. }\end{array}$ \\
\hline
\end{tabular}

Some of the remaining material from Scripture is referred to as well, but these are the only verses the author cites from. In the commentary on this chapter, he has also inserted a quote from Jeremiah 51:7 that describes the Babylonians as the cup of gold in the hand of the Lord. ${ }^{18}$ From the table above it is clear that the author is interested only in the broad outline of the 
story, and pays much greater attention to the dream and its interpretation as a communication from God to the Babylonian king.

Concerning the Commentary's interpretation of the image and its different parts, it can be said that the author is very much in line with the intention of the author of Daniel. The author is mostly concerned with giving a simple explanation of the book. ${ }^{19}$ The Bible text itself tells us that the head of the statue is a symbol of Nebuchadnezzar, and thus of the kingdom of the Babylonians. The commentary "correctly" 20 identifies the chest and arms of silver as the kingdom of the Medes, the body and thighs of bronze as the kingdom of Cyrus the Persian, the legs of iron as the kingdom of Alexander the Greek, and the feet partly of iron and partly of clay as "the ten kings who stood up from the kingdom of the Greeks". In line with the intention of the author of Daniel, the author of the Commentary also identifies the rock that grows into a mountain as "the house of the Maccabees who subdued the kingdom of the Greeks". But since this is the final symbolic element in the dream of the king, he cannot help but to make an adaptation to the interpretation which the author or final editor of Daniel probably had in mind. His quotation and interpretation of Scripture in this part read as follows:

And the God of heaven will establish a kingdom that will not pass forever. Comment: This kingdom is to a people not near, for although it was delineated / imprinted symbolically in the house of the Maccabees who subdued the kingdom of the Greeks; in truth it is fulfilled in the Lord. The rock that was cut out without hands (which was not by hands). For that is the Lord who was born/begotten in feebleness like a rock from the mountain. Comment: From the lineage/descent of the house of Abraham. The Holy Virgin is thus also called "the mountain", for from her he was cut out without hands. Comment: Because there was no sexual union from her, yet the whole earth was filled from her.

Comment: He said this over the Gospel that spread everywhere.

In this case, the author thus makes a distinction between the meaning of the dream حir and dนRivir. He says that it was "symbolically delineated"

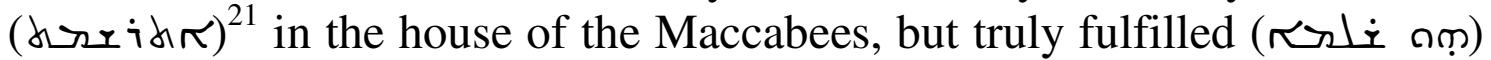
in the Lord (Jesus Christ). This is a technique often used by Ephrem when he interprets the Old Testament as symbolically prefiguring the truth of the New Testament. The commentary is of course not unique in adapting the original meaning to keep it relevant for contemporary believers, since the 
same procedure had already been followed for a long time in Jewish exegesis. As time went by, Jewish exegetes would adapt the interpretation to the times. But, instead of keeping to the original meaning and making a distinction between symbol and truth, the scribes would simply substitute one interpretation for another. 4 Ezra (= 2 Esdras) 12:10-12 and Josephus already interpreted the fourth kingdom as the Imperium Romanum, while it was later interpreted as the kingdom of the Arabs. ${ }^{22}$

The "mountain" in the dream of Nebuchadnezzar is interpreted by the Commentary in two different ways. On the one hand, the author says that it refers to "the lineage/descent of the house of Abraham". On the other hand, the mountain also refers to Mary, since the rock that was cut out from the mountain must refer to Christ. The Christian tradition seems to have made this connection (between the rock in Dan 2 and Christ) much earlier. ${ }^{23}$ Aphrahat has a testimony-series from both Testaments about Christ being identified as the Rock by the prophets, in which Daniel 2 plays an important role. ${ }^{24}$ It must be said here, though, that the way in which the Commentary refers to Mary casts some doubt on the possibility that Ephrem could have written it. To refer to her as "the Holy Virgin" as the Commentary does, seems to be the language of a slightly later age.

The interpretation of the rock in Daniel 2 as referring to Christ was possibly influenced by the phrase "which is without hands". The original meaning of this phrase would have been a pointer to the activity of God, since it is his work to establish the kingdom of the Maccabees. ${ }^{25}$ The author of the Commentary, however, takes this as meaning "without sexual union". Beginning from this premisse, he infers that the rock must refer to Christ, thus the mountain must refer to the Virgin Mary, since Christ was begotten from her without human sexual involvement. ${ }^{26}$ This much is logical, but it is not immediately clear why he makes a connection between the "mountain" in the text and "the house of Abraham". He says:

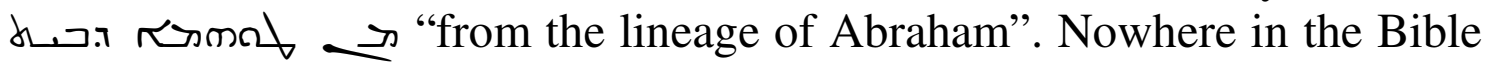
is Abraham's family represented as a mountain. Mary is indeed depicted as a descendant of Abraham (cf. Matt 1:16-17), but it is doubtful whether this text could have provided the link.

The author thus interprets the rock as referring to Jesus Christ. Christ's willingness to be born as a human is commented on with the phrase "the Lord who was begotten in feebleness like a rock from the mountain". The polarity created by the Lord being born as a human, is a favourite theme of Ephrem. ${ }^{27}$ Immediately afterwards, however, the author also interprets the 
rock that grew bigger so as to encompass the whole earth as "the Gospel that spread everywhere". In the Syriac of the commentary, this reads

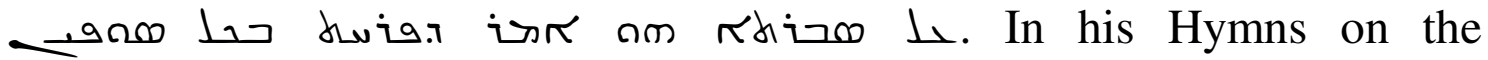
Resurrection 3:17, Ephrem also refers to this rock as a symbol of the propagation of the gospel. ${ }^{28}$ In his exposition of Dan 2:34-44, Aphrahat ${ }^{29}$ similarly shifts from explaining the rock as referring to Christ to the idea that the filling of the whole world is a reference to the faith in Christ. ${ }^{30}$ The Gospel is also involved, however, since he then quotes an adaptation from Ps 19:4 $4^{31}$ which is taken to refer to the "Gospel of the Messiah" and he links this to Matt 28:19. In this regard, Aphrahat, Ephrem, and the author of the Commentary thus share an exegetical tradition.

In the Aramaic text of MT, the word (stone) is used in Dan 2:34 and 45, which is considered to be a masculine noun. In Syriac this has become حم (rock or stone) a feminine noun. The femininity of the word is further enhanced by the addition in Syr of "by her", a feature, as we have seen, which was taken over by the Commentary and which made "the earth" the subject of the verb "fill" in Dan 2:35. Exactly the same version is

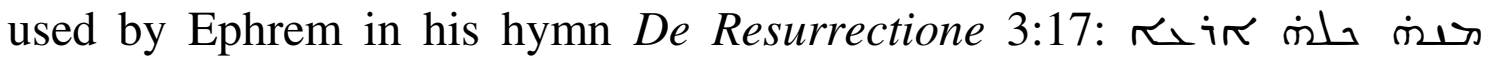
דـ. It is probably this addition, which creates the possibility of introducing a new subject, which provides the opportunity for Aphrahat, Ephrem, and the Commentary to interpret this as a reference to the Gospel. In other words, their interpretation of the Syriac text runs like this:

"And the rock which struck the image became a big mountain.

And the whole earth was filled by it".

$\rightarrow$ Christ.

$\rightarrow$ The Gospel.

Peculiarities of the Commentary encountered so far would thus be that the author is able to interpret the image in line with what the biblical text probably intended, but that he uses symbolic interpretation to extend the reference of the image to the beginning of Christianity and interprets some elements as referring to Christ, his immaculate conception, and the propagation of the Christian faith. In doing so, he makes the message more relevant for his Christian audience.

\section{(2) The author's interest in cause and effect and the role of honour and shame}

A second characteristic of the Commentary is the interest in the cause and effect of things in the text. In this regard, the social and theological values 
of honour and shame also play a very important role. In answer to the question why Nebuchadnezzar had a dream without having its meaning explained to him also, the author answers that it was the intention of the Lord to shame the Babylonian soothsayers and to prepare the triumphant entry of Daniel who would show himself superior to them, but also and especially to point to the power and honour of the God whom the Babylonians thought was inferior to their own gods. The argument runs like this:

And the king said to call the magicians and the charmers: "If you do not make the dream known to me, your judgement is one: through a lying and empty word you agreed to speak before me."

Comment: In the second year of the reign of Nebuchadnezzar, a dream was shown to him but it was concealed from him so that while the magicians and astrologers would be ashamed - those who were thinking that through their magic practices and plans they had raised the Babylonian king to honour - Daniel would enter triumphantly through that God whom they considered to be weaker than the gods of Babylon. And the command went out and the wise were to be killed. He thus decreed death on the Chaldeans so that they would be ashamed. If those of the city who were within it were not able to save themselves, how could they declare to have brought out the inhabitants of Jerusalem who were in captivity? And Arioch went out to kill the wise of Babylon. Through his knowledge Daniel thus turned them away from death, those whose ignorance delivered them to the sword. The wisdom was thus concealed from the wise of Babylon, but it was revealed through prayer to Daniel.

The honour of the God of the Hebrews ${ }^{32}$ is at stake here. ${ }^{33}$ The magicians and astrologers of the Babylonian king thought that their gods were superior to the God of the Israelites. According to them, that is why their army was able to subdue this people. To change this misconception, God gives Nebuchadnezzar a dream, but withholds the interpretation of the dream from him. This provides an opportunity for God to show his superiority over the non-existent gods, and also the superiority of his followers over the followers of those gods. In the end, it would be clear that the powers of the magicians are to no avail; that it was not their gods who gave them victory, but the Lord who had decided to forsake his own people. ${ }^{34}$ Daniel's trust and faith in God will be vindicated and the honour of God will be enhanced ultimately. This argument is pressed further a 
short while later, when the Commentary says that the command of the king, that the wise men must be killed, was given "so that they would be shamed". He argues a minora ad maiorem that the magicians and astrologers should have realised that it could not have been their powers or those of their gods that brought the Israelites into exile, since they were not even able to save themselves within their own city.

The author is still not satisfied, however. God's purpose with the dream was to shame the Chaldeans and their gods. But why did it happen at precisely this time in the reign of Nebuchadnezzar? Because of the thoughts of the king the evening before, the Commentary would answer. In his comment on the phrase "Uncovering the hidden things", the author says: "The dream and its interpretation and the thoughts of the king that came to him in the evening". A short while later, he explains the phrase in Daniel's prayer that "the word of the king you have made known to me" as follows: "The thought of the heart of the king you have made known to me". In conversation with the king, he lets Daniel explain: "What happens, he shows to you, not only the dream and its explanation which was lost to you and your wise ones and your idols, but also those intentions that were the cause for the appearance of the dream". It is the hidden thoughts of the king that caused the chain reaction, and those thoughts that "went up" when the king was on his couch, were about the future. The Commentary tells us: "The thinking of this Babylonian thus was that because he subdued all the nations and he shamed all kings, there would be no kingdom which could cause his kingdom to pass over." This is the cause of everything, and this is also why God sent the dream to him, namely to tell him "who it is who will cause (his kingdom) to pass". In the same vein, the author later comments on the phrase "a humble kingdom" which would succeed that of the king, explaining that this was said because "he (Nebuchadnezzar) thought that no rule of mighty kings could cause their (the Babylonians') kingdom to pass". God's ultimate purpose therefore was to shame the arrogance of the Babylonian and his astrologers through the insight and wisdom he gave to those who fear him.

In line with the biblical text, and in contrast to the arrogance of the Babylonians, Daniel is portrayed by the Commentary as someone full of humility and respect for God. This can be seen clearly in the Commentary on one particular small element of the text. In his comment on the phrase "you have made known to me that which we have sought from you" (Dan $2: 23$ ), the author notes that Daniel said this "so that he would not treat the request of his colleagues wrongly", in other words, so that it would not 
seem that he regarded their prayer as having made no impact on the outcome. The author in fact consistently portrays Daniel as a humble person who shows great respect for God and who succeeds because of this. The irony of the situation is also not lost on him. At the conclusion of this chapter, he notes how the king "thus revered the captive and exiled youth" but in reality worshipped "him who was dwelling in Daniel, the Holy Spirit who was in him."

\section{A comparison between the Commentary's interpretation of Daniel 2 and that of Aphrahat}

Aphrahat did not write a commentary on Daniel, but his Demonstrations basically consist of series of biblical citations and allusions that are interspersed as proof texts between his own argumentative discourses. In his Demonstration V, which has the topic "On Wars", he uses Daniel 2, 7, and 8 to review human history and its destiny and to formulate a reassuring message for his Christian Persian contemporaries. ${ }^{35}$ He probably wrote this particular discourse between September and October 337 C.E. ${ }^{36}$ He seems to have been more concerned with the politics of his own time than the author of the Commentary was. As we have seen, the Commentary correctly identified the kingdoms that were symbolised by the statue in Nebuchadnezzar's dream. Aphrahat, on the other hand, telescopes history so as to be able to find answers from the dream with regard to things that were happening in his own time. He ignores the Persians in the interpretation and lets the Greeks succeed the Medes. The image's legs of iron and the feet of a mixture of iron and clay together are interpreted as the "Children of Esau", a name he uses for the Romans. ${ }^{37}$ In this way, he is able to suggest that the reign of Constantine ${ }^{38}$ will soon crush the kingdom of Shapur II and bring the persecution of Christians by the Persians to an end: ${ }^{39}$

\begin{tabular}{|l|l|l|}
\hline $\begin{array}{l}\text { Nebuchadnezzar's } \\
\text { dream }\end{array}$ & Aphrahat's interpretation & $\begin{array}{l}\text { The Commentary's } \\
\text { interpretation }\end{array}$ \\
\hline Head of fine gold & $\begin{array}{l}\text { Babylonians } \\
\text { (Nebuchadnezzar), or } \\
\text { Babylon as the cup of } \\
\text { gold in the hand of the } \\
\text { Lord }\end{array}$ & $\begin{array}{l}\text { Babylonians } \\
\text { (Nebuchadnezzar), or } \\
\text { Babylon as the cup of } \\
\text { gold in the hand of the } \\
\text { Lord }\end{array}$ \\
\hline Chest and arms of silver & The Medes (Darius) & The Medes \\
\hline $\begin{array}{l}\text { Middle and thighs of } \\
\text { bronze }\end{array}$ & The Greeks (Alexander) & The Persians \\
\hline Legs of iron & Taken together: & The Greeks (Alexander) \\
\hline
\end{tabular}




\begin{tabular}{|l|l|l|}
\hline $\begin{array}{l}\text { Feet partly of iron and } \\
\text { partly of clay }\end{array}$ & $\begin{array}{l}\text { "Children of Esau" } \\
\text { (Romans) }^{40} \\
\text { Iron = the elected kings; } \\
\text { Clay = the hereditary } \\
\text { kings }\end{array}$ & $\begin{array}{l}\text { The ten kings who stood } \\
\text { up after Alexander }\end{array}$ \\
\hline A rock & $\begin{array}{l}\text { Taken together: The } \\
\text { kingdom of Christ; the } \\
\text { return of Christ; the } \\
\text { world = the worldly } \\
\text { kingdoms together; } \\
\text { Gospel }\end{array}$ & $\begin{array}{l}\text { The Maccabees } \\
\text { symbolically, but Jesus } \\
\text { Christ in truth }\end{array}$ \\
\cline { 3 - 3 } & $\begin{array}{l}\text { The kingdom of God; the } \\
\text { Holy Virgin; the Gospel }\end{array}$ \\
\hline $\begin{array}{l}\text { A great mountain that } \\
\text { filled the whole earth }\end{array}$ & &
\end{tabular}

There are some interesting similarities between the interpretation of Aphrahat and that of the Commentary, however. The first is the use of Jeremiah 51:7 as a key to the interpretation of whom the head of gold refers to. In this case, there seems to have been a tradition of interpretation from which both of them could draw. The second similarity is the interpretation of the rock as referring to Christ and of the mountain as referring to the spreading of the Gospel. As we have noted, Aphrahat and Ephrem in this regard shares in a popular tradition of interpreting "rock texts" from the Old and New Testaments as referring to Christ. A third similarity is the importance attached to honour and shame as social and theological values. Morrison $^{44}$ says that Aphrahat "recasts Daniel into the thematic terminology of his discourse (arrogance, boasting, and humbling) with the result that the biblical text better illustrates his themes". In actual fact, the two Syrian exegetes have both picked up the theme of honour and shame as an important axis of interpretation from the book of Daniel itself. The Commentary has rightly pointed out that the whole story of Daniel 2 was intended to illustrate how the God of the heaven shamed ${ }^{45}$ the Babylonian wise men and their gods, those gods whom they thought to be superior to the God of Israel and whom they regarded to have given them victory over Israel. The great king of the Babylonians in the end venerates the youth whom they thought inferior and whom they regarded as worshipping an inferior God. In doing so, Nebuchadnezzar also honours the God who controls history and is therefore (as yet) not shamed himself.

\section{Could Ephrem have written the Commentary on Daniel?}

If only this chapter in the commentary is taken into consideration, ${ }^{46}$ the answer seems to be that it is possible but not probable. Only in one aspect does there seem to be a difference between the Commentary and Ephrem. This is the fact that Mary, who is usually simply called "Mary" by Ephrem 
and is sometimes described by him as "the virgin", is referred to as "the Holy Virgin" in the Commentary. On the other hand, a number of similarities have been pointed out between the Commentary and the work of Ephrem. One of the most outstanding features of Ephrem's hymns is the polarities he constructs with the help of antitheses, types and antitypes, symbols and truth, et cetera. The Commentary on Daniel 2 displays the same interest in polar thought patterns. ${ }^{47}$ The contrast between God and the idols of the Babylonians, between Daniel and his friends' knowledge in opposition to the lack of knowledge of the astrologers of Babylon, and the reversal of roles in terms of the honour and shame of gods and men are highlighted. One such polarity is identified by the Commentary in the text of Daniel 2 when the author highlights the wisdom revealed to Daniel through prayer - wisdom which was hidden from the wise of Babylonia as the interpretation of the dream was also hidden from the king. This polarity is also exploited in one of Ephrem's genuine hymns. In his hymn $D e$ Ieiunio 9:10-13, he describes how "error" (-

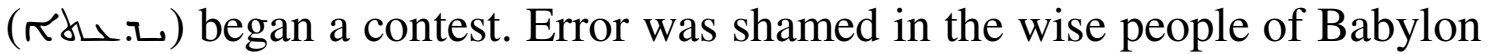
and it lost, but truth was crowned by the youths (Daniel and his friends) and it crowned (honoured) them also. The mourning (fasting) ones of Zion saved and delivered the gluttons of Babylon ${ }^{48}$ because they calmed the anger of the king by quickly donning the fast, the weapon which was also used by the triumphant Moses and Elijah. The fast blunted the sword which was about to kill the wise.

There are similarities between this context and the Commentary, but also differences. Important similarities are the mentioning of the opposition

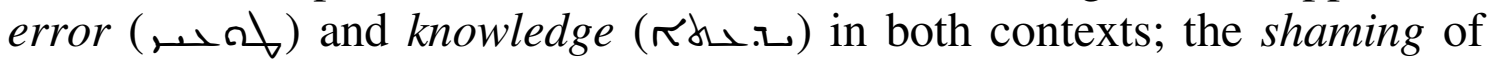
the wise respectively of error in the wise (different Syriac words are used for "shame" and "wise people" in this instance); the opposition of Jerusalem/Zion versus Babylon; wisdom being concealed and revealed through prayer in the Commentary ${ }^{49}$ versus heaven being closed and opened through prayer in the hymn (cf. the same idea of prayer as a key to a treasure house expressed in the hymns De Fide 47:7). In the Commentary it is described how Daniel, through his knowledge, turned away (ngmr) from death those people whose lack of knowledge delivered them to the sword $(\kappa a, \infty)$ ). In the hymn (9:12), Daniel and his friends are said to have saved and delivered (a (a) the gluttons of Babylon (when) the sword $(\kappa a, \infty)$ went out to kill the wise. The word "sword" is a metaphor for death which is not suggested by the biblical context. This points towards a close connection between the Commentary and the hymn. 
In the same hymn, De Ieiunio 9:7, the irony of the one who took people captive (r. act part) throwing himself on the ground before the captive

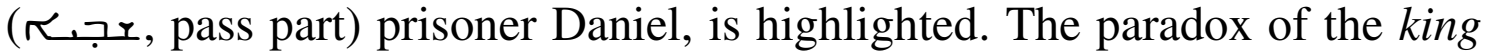
venerating a captive $($ r. $)$ and exiled youth is also mentioned in the Commentary at the end of Chapter 2. In this case, the hymn helps the reader to grasp the impact of the Commentary. This description of Daniel being "captive" is also not in the immediate biblical context and it thus also suggests a close connection between the hymns De Ieiunio and the Commentary. In the light of these and the other similarities between Ephrem and the Commentary mentioned earlier in this paper, it must be concluded that it is perhaps possible that Ephrem could have written it.

\section{BIBLIOGRAPHY}

ABD = Freedman, D N (ed.) [1992] 1997

The Anchor Bible Dictionary. [Electronic Version.] New York: Doubleday.

Amar, J.P. 1994

Introduction and Translation of Ephrem's Commentary on Exodus. In:

McVey, K. (ed.), St. Ephrem the Syrian. Selected Prose Works.

Commentary on Genesis, Commentary on Exodus, Homily on Our

Lord, Letter to Publius, 217-268. Washington, D.C.: The Catholic University of America Press.

Barnes, T.D. 1985

"Constantine and the Christians of Persia", Journal of Roman Studies 75, 126-136.

Baumstark, A. 1922

Geschichte der syrischen Literatur, mit Ausschlu $\beta$ der christlichpalästinensischen Texte. Bonn: A. Marcus \& E. Webers Verlag. Assemani, J S (ed.) 1732-1746

Sancti Patris nostri Ephraem Syri opera omnia quae exstant Graece,

Syriace, Latine, in sex tomos distributa, 2:203-233. Rome.

Bentzen, A. 1952

Daniel. Zweite, verbesserte Auflage. Handbuch zum Alten Testament

19. Tübingen: JCB Mohr (Paul Siebeck).

Braverman, J. 1978

Jerome's "Commentary on Daniel": A study of comparative Jewish and Christian interpretations of the Hebrew Bible. Washington: The Catholic Biblical Association of America.

Bright, J. [1960] 1972

A history of Israel. Second Edition. OTL. London: SCM Press. 
Brock, S.P. 1992

Article s.v. "Versions, Ancient (Syriac versions)", Anchor Bible Dictionary, see under ABD.

Bruns, P. 1991

Aphrahat. Unterweisungen. Erster Teilband. Aus dem syrischen übersetzt und eingeleitet. Fontes Christiani 5/1. Freiburg, Basel, Wien, Barcelona, Rom, New York: Herder.

Collins, J.J. 1993

Daniel. Hermeneia. Minneapolis: Fortress Press.

Gispen, W.H.; Oosterhoff, B.J.; Ridderbos, H.N., (eds.) 1977

S.v. "Noorde". Bybelse Ensiklopedie. [Electronic version.] Kaapstad:

Verenigde Protestantse Uitgewers.

Glessmer, U. 2001

"Die "Vier Reiche" aus Daniel in der Targumischen Literatur", in

Collins, J J \& Flint, P W, The Book of Daniel: Composition and reception, Vol 2, 468-489. Suppl VT LXXXIII,II. Leiden, Boston, Köln: Brill.

Goldingay, J.E. 1989

Daniel. WBC 30. Dallas: Word Books.

HALOT - The Hebrew and Aramaic Lexicon of the Old Testament by Ludwig Koehler and Walter Baumgartner, subsequently revised by

Walter Baumgartner and Johann Jakob Stamm with assistance from Benedikt Hartmann, Ze'ev Ben-Hayyim, Eduard Yechezkel Kutscher, and Philippe Reymond; translated and edited under the supervision of M.E.J. Richardson, (C) 1994-2000, Koninklijke Brill NV, Leiden, The Netherlands.

Jenner, K.D. 2001

Syriac Daniel, in: Collins, J.J. \& Flint, P.W. (eds.), The Book of Daniel. Composition and Reception, Vol. II, 608-638. Leiden, Boston, Köln: Brill.

Mathews, E.G. 1994

Introduction and Translation of Ephrem's Commentary on Genesis. In: McVey, K (ed.), St. Ephrem the Syrian. Selected Prose Works. Commentary on Genesis, Commentary on Exodus, Homily on Our Lord, Letter to Publius, 59-216. Washington, D.C.: The Catholic University of America Press.

McCarthey, C 1993

Saint Ephrem's Commentary on Tatian's Diatessaron. An English Translation of Chester Beatty Syriac MS 709 with Introduction and Notes. Journal of Semitic Studies Supplement 2. Oxford: Oxford University Press. 
Morrison, C.E. 2004

"The Reception of the Book of Daniel in Aphrahat's Fifth Demonstration, 'On Wars'”. Hugoye: Journal of Syriac Studies 7(1), $\S 1-33$. Accessed at http://syrcom.cua.edu.Hugoye.

Murray, R. 1975

Symbols of Church and Kingdom. A study in early Syriac tradition. Cambridge: Cambridge University Press.

Peshitta Institute, The 1980

The Old Testament in Syriac, according to the Peshitta Version. Part III, fascicle 4, Dodekapropheton - Daniel-Bel-Draco. Leiden: E.J. Brill.

Taylor, R.A. 1994

The Peshitta of Daniel. Monographs of the Peshitta Institute, Leiden,

7. Leiden, New York, Köln: Brill.

Wenham, D. 1992

Article s.v. "Abomination of desolation", Anchor Bible Dictionary, see under ABD.

\section{NOTES}

1 Nebuchadnezzar's reign probably began in 605/604 BCE and lasted until 562 BCE. This causes obvious problems with the information in Daniel 1:5 and 18, where it is said that Daniel had three years of training before being brought before the king. It is also clear that, according to the book itself, Daniel and his friends must have been among the exiles brought to Babylon in 587/586 BCE (cf. Dan 1:1-4). By then, Nebuchadnezzar must have been on the throne for about 18 years. Josephus (Ant 10:195) consequently dates the dream of the king two years after the destruction of Egypt, thus in 566 BCE (Nebuchadnezzar invaded Egypt in 568 BCE, cf. J. Bright, A history of Israel, Second Edition (OTL; London: SCM Press, [1960] 1972), 352. Jerome also adopted this explanation in his commentary on Daniel (cf. J. Braverman, Jerome's 'Commentary on Daniel': A study of comparative Jewish and Christian interpretations of the Hebrew Bible (Washington: The Catholic Biblical Association of America, 1978), 72. Seder 'Olam Rabbah (28:124), it seems (idem), has interpreted this as two years after the destruction of the temple. J.J. Collins, Daniel (Hermeneia; Minneapolis: Fortress Press, 1993), 155 notes that the simplest explanation is that the editor of the tales did not notice the discrepancy.

2 Daniel and his friends were included in the eradication command, since they were among the 'wise men of Babylon' (Dan 2:12). This seems unfair, since they were not included among the magicians and sorcerers (Dan 1:20); they were not summoned with the other wise people to explain the dream of the 
king (Dan 2:2); and they were only educated in the literature and language of the Babylonians so as to be able to serve in the administration (cf. the expression to 'stand in the palace' in Dan 1:4; compare this with 'stand before the king' in Dan 1:19, cf. also Gen 41:46, 1 Kings 12:16, et passim). According to Jerome in his commentary on Daniel, the 'Hebrews' whom he consulted solved the problem by suggesting that Daniel and his friends did not go at first so as not to seem eager for the rewards the king would promise, or else that the sorcerers concealed the inquiry of the king from Daniel and his friends to keep any reward from them, but were then afterwards willing to let them share in the same fate as they. Cf. Braverman, Jerome's 'Commentary on Daniel', 77.

3 The metals thus become harder as the value decreases. For a discussion of the problem of the four kingdoms, cf. Collins, Daniel, 166-170. J.E. Goldingay, Daniel (WBC 30; Dallas: Word Books, 1989), 50-57 acknowledges the usual interpretation, but is sceptical about dating the chapter in the Greek period and would rather think of Nebuchadnezzar and his successors within the same kingdom. The editing of the book as a whole, however, definitely suggests the time-frame of the Seleucids. In this regard, cf. Dan 11:6, 17.

D. Wenham, "Abomination of desolation", in Anchor Bible Dictionary (ed. D.N. Freedman; [Electronic Version], New York: Doubleday, [1992] 1997). Cf. ('the abomination that makes desolate') in Dan 11:31, 12:11, (possibly also 9:27), and tò $\beta \delta \delta^{\prime} \lambda u \gamma \mu \alpha$ ('the abomination') in 1 Maccabees 6:7.

$5 \quad$ Cf. Collins, Daniel, 171 n.179; 4 Ezra 13.

6 Cf. Psalm 48:3; Ezek 38:12. Cf. also "Noorde", in Bybelse Ensiklopedie (ed. W.H. Gispen, B.J. Oosterhoff, \& H.N. Ridderbos; [Electronic Version], Cape Town: Verenigde Protestantse Uitgewers, 1977); "טבוּרָא", in HALOT The Hebrew and Aramaic Lexicon of the Old Testament (ed. Ludwig Koehler and Walter Baumgartner, subsequently revised by Walter Baumgartner and Johann Jakob Stamm with assistance from Benedikt Hartmann, Ze'ev Ben-Hayyim, Eduard Yechezkel Kutscher, and Philippe Reymond; translated and edited under the supervision of M.E.J. Richardson; Koninklijke Brill NV: Leiden [Electronic Version], 1994-2000).

7 The Syriac text and Latin translation of this work, a copy of which was sent to me by Prof. Katharina Bracht of the Humboldt University in Berlin, are evidently those prepared by Petrus Benedictus [= Butrus Mubârak] and Simon Evodius Assemani, eds., Sancti Ephraem Syri opera omnia and it seems to be from Tomus II, 203-233.

8 A. Baumstark, Geschichte der syrischen Literatur, mit Ausschlu $\beta$ der christlich-palästinensischen Texte (Bonn: A Marcus \& E Webers Verlag, 1922), 38. 


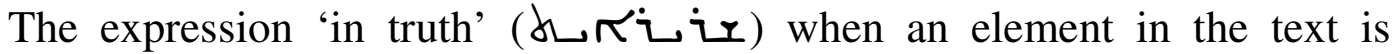
interpreted symbolically, is a feature of the work of Ephrem also. Cf., e.g., his commentary on Genesis Section XLII.5 'it is to be understood, in truth, about the Son of God and not about David...'

C.E. Morrison, "The Reception of the Book of Daniel in Ahrahat's Fifth Demonstration, 'On Wars"', Hugoye: Journal of Syriac Studies 7/1 (2004): $\S 1-33, \S 4$. Accessed at http://syrcom.cua.edu.Hugoye.

Besides the Peshitta, Daniel was later also translated into Syriac in the SyroHexapla (the book of Daniel being translated in $617 \mathrm{CE}$ ). There is also the revision of the Peshitta by Jacob of Edessa, probably made in $708 \mathrm{CE}$ shortly before his death by comparing the Peshitta to the Syro-Hexapla and the LXX (S.P. Brock, "Versions, Ancient Syriac versions", ABD, 1992). Cf. also K.D. Jenner, "Syriac Daniel”, in The Book of Daniel. Composition and Reception, Vol. II (ed. J.J. Collins \& P.W. Flint; Leiden, Boston, Köln: Brill, 2001), 608-638, 608. Both these were thus made long after the time of Ephrem.

R.A. Taylor, The Peshitta of Daniel (Monographs of the Peshitta Institute, Leiden, 7; Leiden, New York, Köln: Brill; 1994), 64-67.

Cf. the exact four words, in this order but without the waw at the beginning, also in Ephrem's hymn De Resurrectione 3:17.

14 Taylor, The Peshitta of Daniel, 67-70.

15 Taylor, ibid., 69.

16 Idem.

17 Idem.

18 The reference to this verse in the interpretation of Daniel 2:38 is a feature Ephrem shares with Aphrahat. This will be expanded upon below.

19 This is a feature of most of the material in Ephrem's commentaries also. Cf. the remark by E.G. Mathews, 'Introduction and Translation of Ephrem's Commentary on Genesis', in St. Ephrem the Syrian. Selected Prose Works. Commentary on Genesis, Commentary on Exodus, Homily on Our Lord, Letter to Publius (ed. K. McVey; Washington, D.C.: The Catholic University of America Press, 1994), 59-216, 60 about most of Ephrem's commentary on Genesis being 'a close literal reading of the text' and Amar's remark that Ephrem is concerned throughout the major part of his commentary on Exodus with 'a straightforward explanation of the significance of the events recorded in the Book of Exodus' (J.P. Amar, Introduction and Translation of Ephrem's Commentary on Exodus, in St. Ephrem the Syrian. Selected Prose Works. Commentary on Genesis, Commentary on Exodus, Homily on Our Lord, Letter to Publius (ed. K. McVey; Washington, D.C.: The Catholic University of America Press, 1994), 217-268, 217. 
This is not meant to imply that there is scholarly consensus on the interpretation of the image. Ethpa $=$ 'to be delineated, imprinted'.

22 A. Bentzen, Daniel (Handbuch zum Alten Testament 19, Zweite, verbesserte Auflage; Tübingen: J.C.B. Mohr 1952) 33. Cf. also syrBaruch 36; 39:5ff; 40:1ff, (U. Glessmer, 'Die "Vier Reiche" aus Daniel in der Targumischen Literatur', in The Book of Daniel: Composition and reception (Suppl VT 83; ed. J. J. Collins \& P. W. Flint, Vol 2; Leiden, Boston, Köln: Brill, 2001), 468-489, 471 n.6) and the interpretation of the כתיאים in the Pesher Habakkuk, from 1QpHab 2:12 onwards.

R. Murray, Symbols of Church and Kingdom. A study in early Syriac tradition, (Cambridge: Cambridge University Press, 1975), 207 notes that the 'stone cut without hands' text in Daniel 2 is the 'most frequent "Stone" testimony to Christ in all the early Fathers'.

Cf. the discussion in Murray (Symbols, 206-212). The complete series consists of Ps 118:22, Isa 28:16, Luke 20:18, Isa 8:14, Dan 2:34-44, Ps 19:4, Matt 28:19, and Zech 3:9, 4:7 and 4:10.

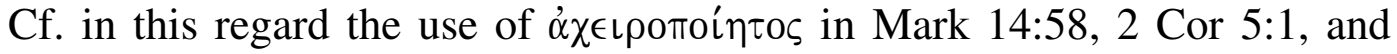
Col 2:11.

26 It seems that Chrysostom (d. 407) also knew this interpretation (Goldingay, Daniel, 60), but Jerome is given the honour of being the first to make this connection (Collins, Daniel, 171). Jerome (331-420) was much younger than Ephrem ( $\pm 306-373)$, however, and began to learn Hebrew a year or two before Ephrem's death! For Ephrem's interpretation of "without hands" implying "without intercourse", cf. his commentary on the Diatessaron II§2 (English translation consulted in C. McCarthey, Saint Ephrem's Commentary on Tatian's Diatessaron. An English Translation of Chester Beatty Syriac MS 709 with Introduction and Notes (Journal of Semitic Studies Supplement 2; Oxford: Oxford University Press, 1993), 61. See, e.g., the Hymns De Nativitate 11:6-8.

He uses the same word for the Gospel and quotes the phrase from the Peshitta inclusive of the addition it contains ('by her') - exactly like the Commentary, but other similarities are limited because he is in this instance more interested in the cloud that Elijah saw as a symbol of the Gospel spreading itself over all peoples. See also Ephrem's commentary on the Diatessaron at Matt 21:42 and Murray (Symbols, 210-211). Dem I.8.

'For, from the faith in Christ all ends of the earth are filled'.

Specifically the phrase 'their message (goes out) to the ends of the world', originally a reference to the heavens and the sky proclaiming the glory of God. Aphrahat changes this to 'for in the whole world the sound of the Gospel of the Messiah went out'. Cf. also the translation and notes of P. 
Bruns, Aphrahat. Unterweisungen, Erster Teilband, Aus dem syrischen übersetzt und eingeleitet (Fontes Christiani 5/1; Freiburg, Basel, Wien, Barcelona, Rom, New York: Herder, 1991), 86 and Murray, Symbols, 207.

The name YHWH is used in the book Daniel only in Chapter 9. Adonai is used in 1:2, and further only in Chapter 9. The usual designation in Daniel is the Aramaic epithet 'the God of the heaven'.

It is interesting to note that Aphrahat, in his discussion of wars - in which the book of Daniel plays a decisive role - takes the theme 'God humbles the arrogant' as a central one (Demonstration V §2,4; cf. Morrison, "Reception of Daniel”, §6).

This is something which the book of Daniel expressly states at its beginning and which the Commentary also picks up: 'Nebuchadnezzar the king of Babylon came to Jerusalem and laid siege to it. And the Lord handed her over into his hands. Comment: As he had before decreed over her through Moses the prophet and the rest of the prophets.' Morrison, "Reception of Daniel", §1.

T.D. Barnes, 'Constantine and the Christians of Persia', Journal of Roman Studies 75 (1985), 126-136.

This interpretation is also known from the Targumic literature, in which Rome is often code-named 'Edom' (U. Glessmer, 'Die "Vier Reiche" aus Daniel in der Targumischen Literatur', in The Book of Daniel: Composition and reception (Suppl VT 83, ed. J.J. Collins \& P.W. Flint, Leiden, Boston, Köln: Brill, 2001), 468-489, 471-486). Cf. the Targums on Gen 15:10-17, Dtn 32:24 and Lev 26:42-44. Some Targums explicitly mention Rome, e.g. Targum Jonathan on the Prophets at 1 Sam 2:5, where Rome as a city is mentioned as the opposite of Jerusalem (Jerusalem was empty like a childless woman, but will be filled by returned exiles; Rome was full of peoples, but will be emptied and devastated); and TgHab 3:17 (the Romans shall be destroyed and shall not collect tribute from Jerusalem). Although he never explicitly refers to 'Constantine' in Dem V. Morrison, "Reception of Daniel", §2.

Ibid., $\$ 21$.

Ibid., §22.

Ibid., \$24.

Cf. Dem I.8.

Morrison, "Reception of Daniel", $\$ 30$.

The theme of honour and shame is present in the biblical text itself: The king promises the soothsayers 'honour' (יקר? and its meaning (2:6); Daniel praises God as the one who sets up kings and removes them (2:21); Daniel gives the honour of interpreting the dream to God (2:28-30); God gave Nebuchadnezzar the power and honour which he enjoyed (2:37-38); an inferior (אִרע) kingdom will follow his (2:39); it is a 
great God who made these things known to Nebuchadnezzar (2:45); the king pays homage (סגד) to Daniel (2:46); Nebuchadnezzar acknowledges Daniel's God as 'the God of gods and the Lord of kings' (2:47); the king made Daniel great (רבה Pa), a ruler over Babylon and the chief prefect over the wise (2:48). The most important theme of the chapter is 'the contrast between the helplessness of the Babylonians' spiritual resources and the power and wisdom of the God of Israel to effect and to interpret history' (Goldingay, Daniel, 37).

I do not want to imply that the other chapters suggest something else, but simply state that I have not investigated them to the same extent.

47 The polarities are perhaps not formulated as often and as explicit in the form of types and anti-types as in his hymns, but this is a feature of the genuine commentaries of Ephrem also. Cf. Mathews' remark in the introduction to the commentary on Genesis: 'Ephrem rarely engages in the typological or symbolic exegesis that so characterizes his hymns' (Mathews, "Ephrem's commentary on Genesis", 60).

It should be kept in mind that these hymns all focus on the advantages provided by observance of the fast.

49 Cf. also Ephrem's hymn Contra Haereses 11:9 which speaks of God making his revelation accessible through prayer, a reference to Daniel 2. 